\title{
Horizontal Local Governance and Social Inclusion: The Case of Municipality-Civil Society Engagement During Refugee Reception in Malmö, Sweden
}

\author{
Claudia Fry and Mine Islar* \\ Centre for Sustainability Studies, Lund University, Lund, Sweden
}

This study takes its departure from literature on the far-reaching engagements from civil society during the 2015 "refugee crisis" in Europe as it seeks to understand the status of collaborative governance at the local level. It takes an in-depth look of Malmö, a city in Sweden which in 2015 became the centre for the Swedish refugee reception and solidarity initiatives. The study identifies challenges and opportunities of horizontal collaborations to develop the social dimension of city resilience. It includes eleven interviews with key actors from the civil society sector as well as from the municipality

OPEN ACCESS

Edited by:

Anitta Kynsilehto,

University of Tampere, Finland

Reviewed by:

Catherine Baillie Abidi,

Dalhousie University, Canada

Shiva Nourpanah,

University of Guelph, Canada

*Correspondence:

Mine Islar

mine.islar@/ucsus.lu.se

Specialty section

This article was submitted to

Refugees and Conflict,

a section of the journal

Frontiers in Political Science

Received: 17 December 2020

Accepted: 15 March 2021

Published: 09 April 2021

Citation:

Fry C and Islar M (2021) Horizontal

Local Governance and Social

Inclusion: The Case of

Municipality-Civil Society Engagement

During Refugee Reception in Malmö,

Sweden. Front. Polit. Sci. 3:643134.

doi: 10.3389/fpos.2021.643134 and utilizes theory on solidarities in the "refugee crisis" together with social cohesion and inclusion as a framework for analyzing data. This allows for a comprehensive appraisal of the (spatially produced) responses to migration from the city's horizontal alliances. The findings suggest that there are diverse conclusions to be made about the long-term potential of horizontal collaborations in bringing about social resilience. On the one side it is discovered that short-term project collaborations may only serve to "fill the gap" left by neo-liberal local governments and not bring about the structural change needed. On the other side, it is found that horizontal collaborations can be a strategy for civil society actors to influence more inclusive alternatives by bringing the realities of refugees into local policy making, particularly those refugees otherwise rendered invisible due to legal categorizations. Lastly, there are suggestions made for how to enhance the opportunities of horizontal collaborations in creating a socially cohesive, inclusive and resilient city.

Keywords: Malmö, social cohesion, solidarity, refugee crisis, horizontal governance, social inclusion, migration governance

\section{INTRODUCTION}

In recent years, local migration governance has become increasingly important in global agendas such as the UN Sustainable Development Goal 11 "Sustainable Cities and Communities" (United Nations, 2020) and the New Urban Agenda (United Nations, 2015). Whilst it is widely accepted that efficient management of migration is a crucial component in the promotion of socially inclusive, resilient and sustainable cities, migration scholars also begin to shift their focus beyond the nation state and toward the local level as a site for debordering practices (Ambrosini, 2018).

In 2015, the Swedish city of Malmö quickly became the center of Sweden's refugee reception, being a transit zone for those who reached Sweden by the bridge from Denmark as well as a city 
in which many refugees choose to reside. Adding to this, the city's already dynamic civil society quickly mobilized a variety of solidarity responses to accommodate the needs of the newly arrived. In Sweden different levels of government have integrated civil society initiatives into migration management as a way of enhancing participation and making use of the innovative solutions that characterize the pro-migrant civil society sector (Statens Offentliga Utredningar 2019;56, 2019). Pries (2019) points to the historical significance of civil society's engagement during the "refugee crisis." Instead of being identified as something to be controlled or directed by politicians, local authorities recognized civil society groups as experts and a substantial infrastructure of refugee aid (Pries, 2019, p. 5). However, some scholars voice concern that the integration of grassroots initiatives into a common urban migration project could de-politicize collective and non-profit action. In turn, this would pose challenges to transforming the structural causes that put migrants in precarious positions in the first place (Stigendal, 2010).

Despite these discussions, there is still limited research focusing on the consequences of civil society-municipal collaborations following the 2015 "refugee crisis" (Caponio and Jones-Correa, 2018; Agustín and Jorgensen, 2019; Frykman and Mäkelä, 2019). This paper aims to address this gap by examining how such collaborations create challenges and opportunities for developing the social inclusion, cohesion, and thus resilience, of the city. The paper does not engage with an in-depth review of resilience theory but refers to the definition of resilience as: "the ability of groups or communities to cope with external stresses and disturbances as a result of social, political and environmental change" (Adger, 2000, p. 347), and views inclusion and cohesion as essential building blocks for this (ARUP, 2014; Townshend et al., 2014; Patel and Gleason, 2018). By using Malmö in the context of the "refugee crisis" as a unit of analysis for our study, we ask: How does Malmö's local migration governance create opportunities and challenges for collaborations between different civil society and state actors? What does this mean for social inclusion and cohesion in the city? Empirical evidence is derived from in-depth interviews conducted with the civil society sector and the municipality. We conclude that migration governance has been colored by a sense of emergency which has resulted in short-term projects aimed to "put out the fire." However, this strategy has failed to deal with the structural causes behind migrants' vulnerabilities in the city. We suggest that there is a need for more long-term civil society-municipal collaboration. This should be based on the aim to bring civil society's socially inclusive practices into policy development rather than on a mechanism to outsource welfare services. We argue that this will support the development of social inclusion whilst building structures that promote efficient and inclusive responses to future crises.

The paper is structured as follows: in section Understanding "crisis" discourse on refugee reception in 2015, it starts with discussing the background of the term "refugee crisis." Third, it presents an overview of the theoretical framework of solidarities and social inclusion. After that, it provides a summary of the Swedish migration regime, the context of the Swedish welfare system, and the case of Malmö. Before presenting the analysis, methodology is presented in section Methodology. Following, the analysis section is explained under three headings, namely the case of horizontal local governance, alliance-building, and dual tensions.

\section{UNDERSTANDING "CRISIS" DISCOURSE ON REFUGEE RECEPTION IN 2015}

Scholars have discussed whether or not the 2015 refugee reception can be considered a "crisis" (Agustín and Jorgensen, 2019). The arrivals of refugees and displaced persons to Europe in reality only constituted 0.25 percent of its population. Whilst, Sweden, with a country of 10 million people, received 163,000 asylum applications during the peak year of 2015 (Migrationsverket, 2020a), Lebanon with a population of six million people hosted, and continue to do so, close to one million Syrian refugees (UNHCR, 2015; Agustín and Jorgensen, 2019). Based on this, Bhambra (2017) opposes the assumption that such a small number of people could be responsible for the breakdown of European institutions. Instead, scholars suggest that the events in Europe could be framed as a crisis of political solidarity as well as governance (Collyer and King, 2016; Lahusen and Grasso, 2018). Others argue that this is a crisis of legitimacy, pointing to the failures of the EU to defend some of its core values of prosperity, peace, and integration and instead practicing exclusionary politics in the wake of the refugee inflow (Dahlstedt and Neergaard, 2016). In connection to this, some scholars display the crisis as not one in Europe, but one of Europe, referring to the deterring liberal values of the EU as its nations called for reconsideration of their commitments to human rights, outsourcing humanitarian obligations to e.g., Turkey (Bhambra, 2017).

In relation to the notion of "crisis", scholars have explored the securitization and politicization of migration, noting that the topic in recent decades has become one of the most frequently debated and strongly politicized (Krzyzanowski et al., 2018). The sustained rise in economic migrants, refugees and asylumseekers since the 1990s has provided a powerful catalyst for a new political discourse on migration (Zetter, 2007). Within this discourse, Zetter (2007) notes a preoccupation by notions of identity and belonging, entrenched in debates about the "other" in the era of global migration. Adding to this, scholars describe a re-bordering of Europe's external borders. In other words, whilst borderless Europe have been less concerned about intraregional migration, the main focus for migration management is on the arrival of third-country nationals to Europe's outer borders (Zetter, 2007; Bloch et al., 2014).

During the "refugee crisis," states shifted responsibilities vertically, toward the inter-/supranational and the local level, and horizontally, toward the non-public sector (Caponio and JonesCorrea, 2018), further intensifying relations across vertical and horizontal levels of governance. For example, the EU member states have given significant power to the $\mathrm{EU}$ in the area of immigration, through e.g., the Common European Asylum System and EU's Family Reunification Directive (Scholten and 
Penninx, 2020, p. 91). However, certain aspects of migration control, such as access to housing, legal advice, and social welfare benefits, are now commonly dealt with at the local level. This has enabled local authorities to challenge hierarchal, statecentered modes of governing, primarily by forming horizontal relations with civil society organizations (Caponio and JonesCorrea, 2018). For example, Catalan city Barcelona is declared as a "Refuge" city by its municipality. Local migration policies have been developed in cooperation with civil society organizations and has enabled more inclusive responses to the "refugee crisis" than that of the Spanish nation state (Agustín and Jorgensen, 2019; Garcés-Mascareñas and Gebhardt, 2020). Moreover, the focus on the local level of migration governance helps to mitigate the "methodological nationalism" which for long has underpinned migration research (Oliver et al., 2020).

However, a prevalent theme in literature identifies civil society participation as a neo-liberal mechanism to outsource and externalize public services to private and non-profit partners. Scholars have noted that when volunteers are left with previously official tasks, the lack of regulation and control of civil society organizations together with insufficient training among volunteers can pose problems especially in the work with vulnerable groups such as children (Righard and Öberg, 2020, Witkowski et al., 2019). From another angle, Törngren et al. (2018) points out that in work with refugee support, civil society organizations should remain independent from political goals of the state as it allows them to maintain their flexible organization structures (Törngren et al., 2018).

\section{THEORETICAL APPROACH: SOLIDARITIES AND SOCIAL INCLUSION}

In this paper, we follow Agustín and Jorgensen (2019)'s definition of solidarity: solidarity is a relational and spatial practice that requires alliance-building between diverse actors and shapes collective identity (Ibid:31). Solidarity is a spatial practice in that it is produced in different spaces such as institutional and is situated in multi-scalar relations. This includes the explanation of the rescaling of solidarity to the urban (local) scale, involving local authorities and non-state actors in urban space. For example, while most citizen mobilization exists in a transnational sphere, they are also deeply rooted at the local grassroot level (Alcalde and Portos, 2018). There are two interlinked aspects of solidarity which are operational for our further analysis of local collaborations: civic and institutional.

The concept of civic solidarity constitutes ways of organizing among civil society that include refugees and NGOs, local communities, and individuals. The degree of contention varies depending on the strategies of the organization, ranging from critical to aiming at increasing influence in policy making. Practices are centered around rights expansion, representing individuals' interests, and sustaining horizontal relations as it shapes new alliances and collective identities (Agustín and Jorgensen, 2019). The position of civic solidarities connects to the rigorous debate on the role of civil society in the current phase of neo-liberal capitalism, where the civil society sector has been affected by privatizations and tends to replace the state in social services provision (Agustín and Jorgensen, 2019; Vandevoordt and Verschraegen, 2019).

Institutional solidarity refers to the formalization of solidarity between the civil society and policy making, enabling structures that cultivate connections between the government and civil society (Agustín and Jorgensen, 2019). It is particularly explored at the urban scale in the context of refugee reception. It can be exemplified in the case of Barcelona "Refuge" City, presenting an institutional adaptation to the "crisis" and the realities of asylum-seekers and refugees in the city. While opposing the more restrictive Spanish government, the 'Barcelona Refuge City Plan' also built preparedness for the reception of refugees. Institutional solidarity at the local level is however constrained by other levels of governance such as control of asylum policy at the national level. In this sense, municipalities also experience a dual tension in practicing institutional solidarity between civic solidarities and formalized rules of the state (Agustín and Jorgensen, 2019).

To operationalize the solidarity framework within local governance agenda, we use social cohesion and inclusion theories. We identify that some underlying structural issues that hinder social cohesion in cities are also areas of contention in refugee reception governance.

As social cohesion concerns society as a whole, it involves various dimensions (Stigendal, 2010) and is scale sensitive (Miciukiewicz et al., 2012). For this reason, the study has limited the theory on cohesion and inclusion to two existential fields. The first one deals with the built environment, housing, and health. Shedding focus on housing systems, Europe is becoming less socially cohesive. Neo-liberal policies, privatizations and the withdrawal of the state has led to a dualist model of housing which is connected to growing inequalities and insecurities (Stigendal, 2010). Proponents of this approach point to the growing number of homeless in Europe, and among those in Sweden, emphasizing strong linkages with the growing migration. In the absence of sustainable asylum and immigrant provision, together with economic and social shifts in Europe, documented and undocumented immigrants have become especially vulnerable in the housing system (Cameron et al., 2020).

The second approach deals with neighborhood development and grassroots initiatives. It explains how new coalitions of local actors can enable new forms of solidarity and responses to the urgency of needs. In this sense, they have the capacity to transform the local institutional framework (Stigendal, 2010) and bring socially innovative changes to public policy that foster social cohesion and inclusion (Miciukiewicz et al., 2012). However, the possibilities for such practices can be limited by bureaucratic forms of co-ordination on public policies (Miciukiewicz et al., 2012). Moreover, with the emergence of horizontal planning practices and thus civil society's increased influence in policies to support social cohesion and inclusion (Miciukiewicz et al., 2012) scholars have also raised some concerns. Stigendal (2010) and Novy et al. (2012), in similarity to literature on solidarities, problematizes the integration of grassroots initiatives into urban governance within the current state of neo-liberal capitalism. There is a risk of de-radicalization 
when local grassroots initiatives are more and more integrated into urban policies. In other words, instead of being set against the social order they become integrated into a common project, sometimes even instrumentalized by local authorities (Stigendal, 2010).

\section{THE SWEDISH MIGRATION REGIME}

The notion of a crisis strongly shaped responses at all levels of government in Sweden. A "system collapse" became a common description among national politicians (Silberstein, 2015). Municipal commissioner of Malmö, finding the city in the center of "the crisis," urged the national government to quickly reach a consensus on the refugee reception (Lönnaeus, 2015). Only weeks later, the vice prime minister broke down in tears during a national press conference declaring the imposition of heavy restrictions on asylum provision (TT, 2019).

Although Sweden has a long history of receiving refugees, 2015 marked a significant increase in asylum applications in all European countries. In 2014, 81,000 applied for asylum in Sweden (Migrationsverket, 2020d) and in 2015 it nearly doubled (Migrationsverket, 2020a). In 2016, the number of asylum applications decreased significantly to only 29000 as a consequence of the shutting of borders and the introduction of ID-controls on the Danish-Swedish border (Lönnaeus, 2016). This marked a closure of what had been called Sweden's "open heart" (Brandel et al., 2015). Since then, Sweden has lowered its laws on asylum to the minimum level required by the European Court of Justice and international conventions (SFS 2016:752).

The Law of reception of asylum-seekers and others divides the responsibility for reception, settlement, and accommodation of the refugee and asylum-seeker between different levels of authorities. During the asylum process, these responsibilities are with the national authority, the Swedish Migration Agency, unless the asylum-seeker is under eighteen in which case the responsibility to provide accommodation is on municipal level (Migrationsverket, 2020b). If asylum is granted the responsibility moves to the municipality in which the new-comer resides (Migrationsverket, 2020c). The Settlement Act (in Swedish: Bosättningslagen), established in 2016, has the overall aim to create a dispersal scheme of those new-comers who during their asylum process resided in Facility Accommodation. The Act makes every Swedish municipality responsible for the reception and settlement of new-comers, including provision of housing (SFS 2016:38).

\section{The Role of Civil Society in Swedish Welfare Model}

In 2015, it was widely recognized by both the general public and politicians that the volunteers who engaged in refugee reception were crucial to managing the situation. As Morgan Johansson, the Swedish Minister of Migration at the time, put it: "If the volunteers did not exist, everything would have crashed a long time ago." (Rydhagen, 2015, as cited in Frykman and Mäkelä, 2019 , p. 293).
Törngren et al. (2018) argue that civil society's role in migration management must be understood in relation to the Swedish welfare state model and its political ideology. Sweden with its traditionally strong public sector have taken on broad social responsibilities for the integration and reception of asylum-seekers and newcomers, dispersing these to different levels of government. So, whilst culture, sports, and politics have been strong areas for civil society, the production of social services has been with the state. However, during the 2015 "refugee crisis," civil society's role in both reception and integration became more intensive and contributed to a larger shift of expectations on civil society to be providers of welfare. During 2015 and after, the government provided large grants to civil society organizations in order to ensure they could continue carrying out integration-related activities (Törngren et al., 2018, p. 15-17). For example, civil society can gain funding through project-based or partnership funding (Törngren et al., 2018), commonly referred to as Voluntary Sector Organization Public Partnerships (in Swedish: Idéburet offentligt partnerskap, IOP).

\section{The Case of Malmö}

Malmö has in several ways been in the center of Swedish refugee reception. A large part of the refugees who came to Sweden in 2015 entered via the Öresund-border and thus came to Malmö first, being the first city after crossing the border. Having one of Sweden's three Migration Agency asylum application centers, it became a transit zone for refugees waiting to be allocated to another municipality (Magnusson, 2015). During October 2015, the media reported around 1,500 asylum applications coming in every day. The Swedish Civil Contingency Agency warned about an overburdened reception system among several municipalities (Rosén and Olsson, 2017) and Malmö was assigned a specific crisis management group as they began running out of accommodation for incoming refugee children (Pedersen, 2015).

The city is a popular place for new-comers and asylumseekers to settle down in. For example, it is one of the largest Free Settlement Act-municipalities, meaning that many asylum-seekers choose voluntarily to reside in Malmö whilst waiting for their decision (Aftonbladets lokalredaktion, 2020). However, municipal reports from Malmö present the increasing vulnerabilities of "new Swedes" in the housing system (Fjellman, 2016; Malmö Stad, 2019; Stadsbyggnadskontoret, 2019). For example, a predominant part of Malmö's homeless share a background as refugees (Malmö Stad, 2018), suggesting that housing exclusion and lack of cohesion in terms of housing is a pressing issue in Malmö's migration management. In 2016, 612 out of Malmö's 1740 homeless adults had been in Sweden for 3 years or less (Fjellman, 2016). According to local civil society organizations, additionally hundreds of people are homeless in Malmö but not included in statistics because of their status as undocumented refugees (Nord, 2019). Shortage of housing for low-income people, with few private property owners accepting tenants on subsidy support (Fjellman, 2016), is partly an explanation for Malmö's high number of homeless people (Malmö Stad Kommunfullmäktige, 2018; Stadsbyggnadskontoret, 2019). In order to combat 
housing-related issues, Malmö municipality have engaged in collaboration with organizations and networks from the civil society.

\section{METHODOLOGY}

This study is designed as a qualitative case study in order to gain an in-depth understanding of the context and complexity of the case (Punch, 2005). Overall, this study includes a total number of thirteen participants which have taken part in eleven different semi-structured interviews. Nine of the participants are from the civil society sector and four are from the municipality.

Participants were selected on the criteria that they were key actors of the "refugee reception" management in Malmö in 2015. Hence, they have good insight into the organization or network they represent and the collaborations that formed. This study does not include interviews with refugees that came to Sweden in 2015 or a focus on their experiences of horizontal migration management. This is due to our focus on the relation between municipality and those actors who identified themselves as "civil society" (including those representing refugee and asylum-seekers' rights). Our aim is to understand the dynamics of horizontal migration governance through conversations with those involved in creating it. Hence, whilst some of the interviewees may have a background as asylum-seekers, they were not interviewed on the basis of this but rather on the basis of their involvement in migration management.

The first interviews were with participants who have been subject to media coverage due to their work. One is from the Swedish Church and one is from Refugees Welcome Sverige $^{1}$. Followingly, we used snowball sampling, building on the contacts of our interviewees. The strategy helped to reveal the interconnectedness of the actors and their shared networks (Bryman, 2012, p. 424), citing a participant saying:

There were some people you always saw in every context; it was like an unofficial network.

(Refugees Welcome Sverige, 20/03/2020)

Moreover, interviewees from the municipality came from the agency for public management, a public-private coordination program, and the department for housing and establishment. All of them had been directly involved in work related to reception and integration. Interviewees from the civil society sector came from more and less institutionalized groups, networks, and organizations. Two participants come from Kompassen; a project based in the neighboring city of Lund that received governmental funding to accommodate asylum-seekers over eighteen. As the geographical limit of the study is set to Malmö only, the interview is not used for the analysis but rather served as background information. Another participant belongs to the Swedish Church in Malmö. The church opened the doors to a church building in central Malmö for asylum-seekers who were made to sleep out on the streets due to over-crowded reception facilities

\footnotetext{
'Sverige' is used here because Refugees Welcome Sweden constitutes a different organization.
}

(Nordström, 2015). The fourth participant belongs to both Refugees Welcome Sverige, a network of activists and volunteers which emerged in 2015 to mobilize support for the arriving refugees, and Skåne Stadsmissionen, the regional chapter of a national organization which works with homelessness prevention and support. Moreover, another participant is an activist from the Asylum Group (in Swedish: Asylgruppen), an organization and network involved in both practical work, such as legal support, and political advocacy around the right of asylum (Asylgruppen i Malmö, 2020). Another interviewee comes from Meeting-place Otto (in Swedish: Mötesplats Otto), a local group offering various forms of social support. The group is operated by the National Association of Unaccompanied (in Swedish: Ensamkommandes Förbund). Lastly, two interviewees came from the regional chapter of Save the Children Sweden and one from Refugees Welcome Housing, a group working on finding alternative housing solutions for refugees and asylum-seekers in the city.

The interview questions followed the topics of (i) generally about their role in migration management; (ii) experiences of horizontal collaborations; (iii) relations with the municipality/ the civil society sector; (iv) views on social inclusion and cohesion; (v) their experiences of working with different groups (e.g., asylum-seekers, new-comers, and undocumented refugees). All interviews were conducted in Swedish and the quotes used in this study have been translated into English by the researchers.

The analysis has followed a thematic approach, meaning a search for themes in the data that can be used to answer the research questions. The analysis was initiated with an open coding in the software program NVivo in which data was broken down and categorized (Bryman, 2012, p. 569), creating a great amount of codes. The codes were then reviewed and some codes covering the same phenomena were deleted. At a third reviewing of the data, the relevant codes were put into five larger themes which all had a connection to the theoretical literature: (i) shortterm project form; (ii) alliance building; (iii) inclusion beyond legal status; (iv) reaching out; (v) dual tension.

\section{THE CASE OF HORIZONTAL LOCAL GOVERNANCE DURING THE REFUGEE CRISIS IN MALMÖ}

Garcés-Mascareñas and Gebhardt (2020) notes a tendency to generalize the role of cities in integration governance meaning that they are sometimes idealized as more inclusive. In an attempt to move beyond idealizations this study critically examine the design of horizontal collaborations and its inherent contentions. Throughout the interviews with civil society sector members, and particularly those from more institutionalized organizations like Save the Children, a prevalent theme was the problematization of the projectform of collaboration. This deserves attention and a more critical examination. For example, four civil society interviewees expressed concerns that short-term, project-like collaborations create obstacles for influencing long-term policy change to improve the structures that put migrants in precarious and vulnerable positions. 
Interviewees from Save the Children (21/04/2020), Refugees Welcome Housing (20/04/2020) and Skåne Stadsmissionen (20/03/2020) express a strong awareness of their problematic role in project-like horizontal collaborations that focus on social service provision. In particular, the struggle to find a balance between being a provider of social services whilst also aiming to influence social change is discussed. In the interview with Save the Children this is emphasized as a continuing complexity of horizontal collaborations with the local government.

In more detail, the organizations provide some alternative social services, such as housing assistance, constituting additional support to migrant groups than that provided from the municipality. At the same time, the interviewees contest performing tasks that they believe should belong to the municipality. For example, one interviewee expresses it in these words:

Sometimes it is that we use the word collaboration but actually we are doing something that the municipality should be doing. So, the answer is that it is not easy. Because we want to work on improving the lives for individuals and for children where we see that: "We want to change this," but it is not always easy because in reality we might be doing something that is the responsibility of the municipality. But it is also a way of saying: 'Okay, we are working on this issue and it is important that we work on the issue, but how do we deliver it to the municipality so that in the end they implement the work that we do.' (...) It is such short projects, like 1-year projects. We have to take 6 months to reach a consensus, and then it is just 6 months left and then we need to show our results and the municipality doesn't even have time to implement the new ideas. (...) It is not easy, and it is something we need to problematize time after time. To not just receive and deliver but that there must be an awareness among civil society actors to be the one to raise awareness about needs and stand on the side of the most vulnerable or with a group whose rights are not respected.

(Save the Children, 21/04/2020)

This adds into the academic discussion on whether and how civil society should compete with, ask for, or substitute state activities, discussed in several studies on civil society during the 2015 "refugee crisis" (Pries, 2019; Garcés-Mascareñas and Penninx, 2020). Moreover, it is in line with theories applied to this study, problematizing the involvement of civil society in welfare services provision (Agustín and Jorgensen, 2019; Vandevoordt and Verschraegen, 2019) and de-politicization of civil society when integrated into urban policy (Stigendal, 2010). However, the interviewee also recognizes that carrying out welfare services is a way to illuminate otherwise hidden problems and needs among refugee groups. In this sense, offering alternative, more inclusive practices is part of a strategy to influence policy-making and building horizontal relations with the local government. This strategy is emphasized in an interview with Save the Children:

We have to be careful with not pointing out the municipality as doing everything wrong because it weakens them. Our aim is that the municipality act much more efficiently and better (...) We want to maintain that balance around that it is not us and them but how can we contribute to making it better.

(Save the Children, 21/04/2020)
The position of civil solidarity organizations as a social service supplier is also discussed by the interviewee from Refugees Welcome Housing. In collaboration with Malmö municipality on a project for housing assistance, the respondent explains that it was important to clarify their role in the collaboration and to detach themselves from any supplier-customer relationship:

This paragraph 37 project that we had with Malmö municipality, it was really important for us that we couldn't guarantee how it will be (...) We will not take a number and promise to deliver. You are not our customer.

(Refugees Welcome Housing, 20/04/2020)

The interviewee also expresses, in similarity to Save the Children, how project collaborations in migration management are sometimes experienced as a way for the municipality to escape responsibilities by making use of the active civil society. The quote is from a conversation on the young asylum-seekers who when turning eighteen had to move from the municipality they were assigned to when under eighteen:

It led to many youngsters being homeless and that's when all the caregiver-homes [in Swedish: fadderhem] started. But instead of taking responsibility and saying: "Okay, now we have all of these youngsters who doesn't have anywhere to stay," and deciding to offer them something else, they say: "It is so good that we have such an active civil society so we will give these millions to a bunch of organizations as a project."

(Refugees Welcome Housing, 20/04/2020)

In this sense, the experiences of the interviewees show that horizontal collaborations are not a friction free process. We argue that friction emerges partly from differing perceptions of solutions toward cohesion and inclusion. For example, four civil society interviewees display a perception of social cohesion and inclusion as one where civil society actors and their bottom-up strategies should be included in, not just problem-solving practices, but long-term policy work. This connects to the second existential field of cohesion, emphasizing a cultivation of horizontal relations in urban governance (Miciukiewicz et al., 2012) with the aim to create long-term collaborations. In contrast, the study displays a short-term problem-solving approach among municipal respondents. For example, a respondent from the municipality confirms a view on civil society as one that complements the municipality in areas of failure:

Generally, we see that civil society complements in areas that we ourselves do not really handle well. In Malmö there is a pretty high degree of homelessness and in the winters, it is a pretty big problem. We have had different collaborations with different civil society organizations to offer places to sleep.

(Malmö Municipality, 17/03/2020)

In addition, all four respondents from the municipality mentioned that they benefit from their collaboration with civil society organizations as they often possess an ability to reach out to the people in need, the "target group" of the collaboration. A respondent from the municipality expressed it like this: 
If for example the labor market administration and the social administration recognize a need to reach out to young people that are neither working nor studying, to put in some efforts there, they can't even find them. Then there's a need to collaborate with some organizations.

(Malmö municipality, 17/03/2020)

Another interviewee from the municipality elaborates on this, explaining that although it is first and foremost the responsibility of the municipality, the civil society sector's ability to reach out to vulnerable groups provides important insights to the public sector:

It [horizontal collaboration] is really valuable (...) for us who work in the public sector in order not to lose touch with reality. It is the civil society sector that has that experience and who knows best. It is important in order to find a solution to the challenges we face.

(Malmö municipality, 23/03/2020)

Hence, rather than connecting to an approach where bottom-up initiatives truly innovate governance frameworks (Miciukiewicz et al., 2012), we argue that the perceptions of municipal respondents connect to an "activating" or "enabling" approach. In this sense, the government keeps its main responsibility whilst also promoting an infrastructure of civic engagement which can be instrumentalized to find specific solutions at specific times of crises (Gerometta et al., 2005; Pries, 2019). However, with the background of theory (Stigendal, 2010), we argue that shortterm collaborations aimed to only ease the city's most urgent humanitarian issues, raise questions about the viability of such in truly addressing the underlying structural causes and thus supporting inclusion and cohesion in the city.

\section{Alliance-Building}

However, the findings also show that due to pressing humanitarian concerns regarding refugees in the city, civil society actors experienced an increased alliance-building and coordination between each other. This enabled them to support a wider group of refugees. In solidarity theory, alliance-building is crucial in order to enable a more inclusive community by giving voice and legitimacy to migrants' claims and acting beyond distinctions between those with documents and not (Agustín and Jorgensen, 2019). This connects well with the experiences of the civil society interviewees in this study.

In more detail, three interviewees (Skåne Stadsmissionen, 20/03/2020; Refugees Welcome Housing, 20/04/2020; Save the Children, 21/04/2020) mentioned an intensification of collaborations between civil society organizations following the 2015 refugee reception. Interviewees described this as a way of meeting the various needs of refugees, asylum-seekers, and newcomers in the city. The actors made sure to supplement each other, phasing out any sort of competition between each other. Whilst some literature on civil society in neo-liberal capitalism explains that NGOs are put in a position of competing with each other for government contracts on service provision (Kaldor, 2003), the findings of this study points rather to the opposite. Due to the urgency of needs among a diverse group of refugees, civil society actors in Malmö are incited to work with each other. The more institutionalized organizations, perhaps more likely to receive government grants due to their formalized nature, could share financial resources with less formalized groups or networks by for example outsourcing tasks. In another example, Skåne Stadsmissionen, being responsible for a housing project which received state funding, initiated the project by getting into contact with other local civil society actors. The respondent explains the importance of intra-organizational cooperation:

We got the money without applying for it and it is even more important that we cooperate so that we use the funding in the best way possible, so that we see that they reach a large group as possible. We started cooperating quite early on and we still do today. We have perfect knowledge of our different initiatives and can distribute the resources in the best way possible. We are all good at different things.

(Skåne Stadsmissionen, 20/03/2020)

Moreover, an interviewee from Save the Children explains that a consequence of 2015 was the creation of a local collaboration platform involving local pro-migrant civil society organizations with the purpose of raising identified needs of refugee groups. The respondent further explains a shift toward a more collectivist approach among involved actors from the civil society:

It no longer feels alien to cooperate with others. I see a change there between organizations. There has been a quite individualistic way of thinking, but the need of supplementing each other is much greater.

(Save the Children, 21/04/2020)

These coordination strategies can be interpreted as important for fostering social cohesion. The continuous mobilization of diverse urban resources, connecting different actors in different locations and scales, is seen as key to introduce new forms of governance which can bring solutions to support social cohesion (Miciukiewicz et al., 2012).

Moreover, our findings suggest that alliance-building is also utilized to overcome exclusion of undocumented refugees. Three interviewees (Skåne Stadsmissionen, 20/03/2020; Refugees Welcome Housing, 20/04/2020; Save the Children, 21/04/2020) talk in particular about the difficulties of addressing this group in municipal collaborations and emphasize their increased vulnerabilities as little to no government support reaches the group:

The housing situation for undocumented youngsters and families ... it is only the civil society, groups, organizations, and volunteers who help them.

(Save the Children, 21/04/2020)

A large part of those we work with are undocumented youngsters and families. It is an increasingly large group. And we can't really apply for funding for these. It is hard (...). Our mission is to always work for everyone, the most vulnerable in society. And right now, it is increasingly the large group of undocumented families, children, youngsters, and adults.

(Skåne Stadsmissionen, 20/03/2020) 
Although horizontal collaborations with the municipality rarely include work with undocumented, the interview with Refugees Welcome Housing exemplifies how alliance building with other civil society actors enables work around the "legal membership exclusion." In more detail, the organization was involved in a collaboration with Malmö municipality aiming to match tenants with a new-comer who had been assigned to the municipality under the Settlement Act. Parallelly however, the organization also supported undocumented refugees in finding housing through collaboration with other local organizations:

\begin{abstract}
If we get an accommodation where the tenant wants rent, then we will turn to Malmö municipality and see if there is anyone [a new-comer under the Settlement Act] interested in moving in. But if someone offers free accommodation then we are also in contact with the Asylum Group and SQU [Scania Queer Initiative] who work a lot with undocumented refugees, and then we will work with them. We do this project with Malmö municipality, but it will still mean that we continue our work with undocumented refugees.
\end{abstract}

(Refugees Welcome Housing, 20/04/2020)

The formation of alliances thus enables Malmö's refugee organizations to enact alternative inclusive imaginaries where legal membership categories are overcome. This conclusion builds on solidarity theory, arguing that solidarity actors practicing radical imaginations have the ability to take the possibilities from the future into the present, inspiring new forms of solidarity today (Agustín and Jorgensen, 2019, p. 35). At the same time, the exclusion of undocumented refugees from municipal collaborations display the limits of horizontal collaborations in promoting radical social inclusion which transgress legal categories. Instead, the findings of this study suggest that alternative imaginaries of an inclusive city, where legal membership does not determine accessibility to housing, are enacted outside of official horizontal collaborations and through intra-organizational coordination. However, it should be emphasized that the ability to enact more inclusive ways exists because civil society groups, when partaking in horizontal collaborations, are not pushed by the local government to adhere to the same political values. Instead, they are able to maintain their flexible structures. This supports Törngren et al.'s (2018, p. 21-22) claims on the importance of allowing civil society organizations to remain independent from any political outlooks of the state.

\section{Dual Tensions}

Although integration policy in recent years has gone through a "local turn," shifting power horizontally (Scholten and Penninx, 2020, p. 91; Oliver et al., 2020), solidarity is expressed under the constraints of other scales (Agustín and Jorgensen, 2019, p. 102). In this case, we witness the constraints of solidarity imposed by the national level of asylum policies and crisis coordination.

Five interviewees (Meeting-place Otto, 19/03/2020; Asylum Group, 14/03/2020; Skåne Stadsmissionen, 20/03/2020; Refugees Welcome Housing, 20/04/2020; Malmö municipality 03/04/2020) point to the strong exclusionary force of Sweden's implementation of temporary asylum. Two interviewees mention poor mental health and an increase of drug abuse among those affected by the law:

Many youngsters are worried about what will happen, and it is a really bad situation. Many are not feeling well. They go into drugs and criminality and it is dangerous for society, others, and themselves.

(Meeting place Otto, 19/03/2020)

In addition, respondent from Refugees Welcome Housing (20/04/2020) and respondent from the Asylum Group describe that the restrictiveness is limiting mobilization of activists and volunteers, as it creates a sense of hopelessness among those who work with the group:

Before 2015 I felt that as long as you fight, you will get to stay. I could say that with honesty. We will not give up; we will support you. But now it is like, well you will probably not get asylum. It is much, much harder. I think that broke down many activists too, that less people engage because it is hard to work against a wall.

(The Asylum Group, 14/03/2020)

Beyond this, the findings of this study show that the ability to utilize local collaboration platforms in times of crises can be limited by formalized agreements on the national level. Theory on solidarity with a focus on scale allows us to understand the "dual tensions" between and across scales (Agustín and Jorgensen, 2019). In this part of the analysis, this becomes useful for understanding the challenges to utilizing everyday horizontal collaborations in order to enhance the resilience of the city in times of national crises. Further explained, an interviewee from Malmö municipality (03/04/2020) explains that cooperation is sometimes limited by formalized agreements or differing perceptions on the national level, hindering locally based organizations to efficiently cooperate with the municipality. In 2015, the interviewee attempted to create a collaboration between the National Migration Agency and Counter Point in order to give recognition and economic support to Counter Point for their extensive solidarity work. However, because of differing perceptions of the crisis the National Migration Agency did not see a need for collaboration with the Malmö-based organization. Similarly, the interviewee describes a situation with the Malmö Muslim Federation:

I talked with those who are in the network, who called me on the night of the 8th of September [to inform about refugees arriving at the Central Station] about the possibility of having a dialogue with the National Migration Agency and hiring [the Malmö Muslim Federation] them as an emergency accommodation and covering the costs for that. Since it wasn't about unaccompanied children, which we had already dealt with (...) we thought it was the National Migration Agency that should cover the cost of those initiatives (...) So I tried to talk with the National Migration Agency about using these organizations. Both the Muslim Federation and Counter Point had already built up a structure. It was amateurish, but still, no one had anything better. But it did not work out.

(Malmö municipality, 03/04/2020) 
For institutional solidarity to be made real in a similar sense to the Barcelona Refuge City Plan, promoting resilience and crises preparedness, there needs to be a fostering of cooperation between the local government and local civil society groups (Agustín and Jorgensen, 2019). However, during the Covid19 pandemic the interviewee expressed similar constraints to collaborating with Malmö-based organizations, imposed by the national level:

\begin{abstract}
Conversations about coordination of volunteers are being made with the Swedish Civil Contingencies Agency and those that they have collaborations with, like the Red Cross, Save the Children, the Swedish Church. But that becomes very strange on a local level. Because yes, they are big organizations but maybe not tone giving for Malmö. Then it is strange for us to, on the premises of the Swedish Civil Contingencies Agency, having to collaborate with them (...). In my everyday work I talk with the Malmö-Muslim network who brings together nine large mosques, gathering thousands of people every Friday. It's a gigantic communication channel and then ... the Red Cross. We haven't spoken to them since 2015, but their role is self-evident. Of course, MSB [the Swedish Civil Contingencies Agency] can't create 290 different platforms for coordinating volunteers, but there needs to be some change, and we haven't really done anything there. We need to think with 2015 in our minds, how to do it, to make sure we don't end up in a similar situation as we did with the Muslim Federation and Counter Point then.
\end{abstract}

(Malmö municipality, 03/04/2020)

In other words, the willingness to develop a more efficient platform for cooperation with local civil society groups in times of crises is limited by agreements and perceptions on the national level. The municipality thus experiences the dual tension of the state in the form of formalized national agreements, and with the local civil society organizations with whom they work with on an everyday basis but whose initiatives are not utilized appropriately. The findings of this study thus elaborate on solidarity theory on 'dual tensions' (Agustín and Jorgensen, 2019, p. 98), demonstrating the ways these creates challenges for accurate responsiveness to crises at the local level.

However, the same interviewee puts great trust in the ability of civil society to manage crisis, allowing for a recognition of civil society's role as essential for social resilience:

\begin{abstract}
"Whilst we are busy planning, the civil society finds solutions on their own. It's cool to work in a city with such an active civil society where people quickly take initiatives. It doesn't matter what happens in the world, you can be prepared to see a manifestation 2 days later. We [the municipality] are one step behind, but it's cool to feel that if we would crash, they would be able to sort it out."
\end{abstract}

(Malmö municipality, 03/04/2020).

\section{CONCLUSION}

This study shows that civil society actors bring a "frombelow" perspective into collaborations with the municipality which, on the basis of theory (Miciukiewicz et al., 2012), we interpret to hold an opportunity for developing policy promoting social cohesion and inclusion. In addition, some of the civil society actors view welfare services provision as, although contested, an opportunity to enact more inclusive alternatives to migration governance. These claims find support in theory applied to this study (Agustín and Jorgensen, 2019). From this perspective, horizontal collaborations may enable responses that are more adapted to the realities of refugees and thus support the development of a more socially cohesive and inclusive city.

This study also illuminates opportunities for inclusion brought by alliance-building between civil society actors. Alliance-building allows for more coordinated responses to the needs of refugees. It also enables civil society groups to enact an imaginary beyond legal categories, giving visibility to the claims of undocumented whom are otherwise rendered invisible in local migration governance. Although this is achieved outside of municipal collaborations it is nevertheless facilitated both by increased governmental funding for initiatives aimed to promote social inclusion and the fact that civil society groups are able to maintain an independent position from the political goals or values of the local government.

A central challenge is that horizontal collaborations tend to be short-term with the purpose of easing the most urgent issues, rather than focusing on long-term policy changes aimed to address the structural causes behind lack of cohesion and inclusion. Critique expressed by interviewees to such forms of collaboration has strong linkages to theory on both civic solidarity in neo-liberal capitalism (Agustín and Jorgensen, 2019, p. 86) and the dilemmas of integrating bottom-linked initiatives into urban governance (Stigendal, 2010; Novy et al., 2012). We found friction to emerge from differing perceptions of what collaborations should be used for.

For example, among municipal respondents, the data displays limited coherence between their perceptions of cohesion and the approaches presented in the theory section. The conclusion is that (horizontal) migration management from the municipal side during the "refugee crisis" was very much colored by a sense of emergency. In turn, this shaped responses and collaborations to focus on "putting out the fire" rather than promoting holistic, long-term solutions that could curve the exacerbated vulnerabilities and exclusions following the "crisis."

Moreover, it was discovered that agreements on the national level sometimes impose restraints to local horizontal relations and the utilization of these to create inclusive response efforts in times of national crises. In order to address this, we suggest increased coordination between the national level of crisis management and local civil society groups. Considering the quick mobilization of Malmö's civil society, we argue that this would build resilience to other crises, such as the health crisis of COVID-19. For example, through increased coordination between levels and spheres of governance, local authorities would be able to better make use of the socially inclusive practices, communication channels, and "onthe-ground knowledge" offered by civil society groups. In addition, a larger local collaboration platform could strengthen 
the position of local civil society actors as contributors to policy development aimed at supporting social cohesion and inclusion at the local level. Elaborating on this, we argue that if horizontal collaborations are to be used for developing social cohesion and inclusion, they should involve long-term collaboration and comprehensive goals. It is essential that civil society organizations are not only executors of municipal responsibilities but have the position to challenge exclusive ways of migration management and bring new imaginaries into policy development.

\section{DATA AVAILABILITY STATEMENT}

The datasets presented in this article are not readily available because sensitive information from the governors may not be shared publicly. Requests to access the datasets should be directed to mine.islar@lucsus.lu.se.

\section{ETHICS STATEMENT}

The studies involving human participants were reviewed and approved by LUND UNIVERSITY. The patients/participants provided their written informed consent to participate in this study.

\section{REFERENCES}

Adger, W. N. (2000). Social and ecological resilience: are they related? Progr. Human Geogr. 24, 347-364. doi: 10.1191/030913200701540465

Aftonbladets lokalredaktion (2020). Beslutet klart: Malmö vill undantas från ebo-lagen. Aftonbladet 30 March. Available online at: https://www.aftonbladet. se/nyheter/a/g7n7n1/beslutet-klart-malmo-vill-undantas-fran-ebo-lagen (accessed on April 16, 2020).

Agustín, O., and Jorgensen, M. (2019). Solidarity and the 'Refugee Crisis' in Europe. Cham: Palgrave Macmillan.

Alcalde, J., and Portos, M. (2018). Refugee solidarity in a multilevel political opportunity structure: the case of Spain. In: Della Porta, D, editor. Solidarity Mobilizations in the 'Refugee Crisis' (Cham: Palgrave Studies in European Political Sociology), 155-178.

Ambrosini, M. (2018). Irregular immigration in Southern Europe. Cham: Palgrave Macmillan.

ARUP (2014). City Resilience Framework, City Resilience Index. London: Arup. Available online at: https://www.urban-response.org/system/files/content/ resource/files/main/city-resilience-framework-arup-april-2014.pdf

Asylgruppen i Malmö (2020). Om. Available online at: https://asylgruppenimalmo. se/om (accessed on Febuary 12, 2021).

Bhambra, G. (2017). The current crisis of Europe: refugees, colonialism, and the limits of cosmopolitanism. Eur. Law J. 23, 395-405. doi: 10.1111/eulj.12234

Bloch, A., Nando, S., and Roger, Z. (2014). Sans Papiers: The Social and Economic Lives of Young Undocumented Migrants. London: Pluto Press.

Brandel, T., Delling, H., and Eriksson, G. (2015). Öppna hjärtan - stängd gräns: Så svängde Sverige. Svenska Dagbladet, 13 November. Available online at: https:// www.svd.se/fran-oppna-hjartan-mot-stangda-granser (accessed on April 15, 2020).

Bryman, A. (2012). Social Research Methods. 4th Edn. Oxford: Oxford University Press, 418-580.

Cameron, S., and Gilroy, R., and Miciukiewicz, K. (2020). Social Cohesion in Housing and Neighbourhood Researching Europe. Social Polis. Available online at: https://www.academia.edu/1562909/Social_cohesion_in_housing and_neighbourhood_research_in_Europe (accessed on April 17, 2020).

\section{AUTHOR CONTRIBUTIONS}

MI add theoretical reflections and contributed to the design of the paper. CF took the lead in writing, data collection, and analysis. All authors contributed to the article and approved the submitted version.

\section{FUNDING}

This project has received funding from the European Commission's Horizon 2020 Research and Innovation Programme under Grant agreement number 822806. MAGYC: The MAGYC (MigrAtion Governance and AsYlum Crises) project seeks to assess how migration governance has responded to the recent refugee crises and has since been influenced by it, and how crises at large shape policy responses to migration. This 4-year research project (2018-2022) brings together twelve international partners: the Hugo Observatory from the University of Liège (Coordinator), Sciences Po, the University of Economics in Bratislava, the GIGA institute of Global and Area Studies, Lund University, the IDMC, SOAS University of London, the University of Milan, the Lebanese American University, the University of Macedonia, Sabanci University, IfPO/CNRS.

Caponio, T., and Jones-Correa, M. (2018). Theorising migration policy in multilevel states: the multilevel governance perspective. J. Ethnic Migration Stud. 44, 1995-2010. doi: 10.1080/1369183X.2017.1341705

Collyer, M., and King, R. (2016). Narrating Europe's migration and refugee 'crisis'. Human Geogr. 9, 1-12. doi: 10.1177/194277861600900201

Dahlstedt, M., and Neergaard, A. (2016). Crisis of Solidarity? Changing welfare and migration regimes in Sweden.

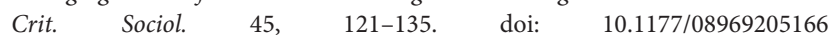
75204

Fjellman, E. (2016). Malmös nya hemlösa är flyktingar. Sydsvenskan. Available online at: https://www.sydsvenskan.se/2016-12-26/malmosnya-hemlosa-ar-flyktingar? redirected $=1 \quad$ (accessed on February 01, 2020).

Frykman, M. P., and Mäkelä, F. (2019). “'Only Volunteers'? personal motivations and political ambiguities within the refugees welcome to malmö civil initiative," in Refugee Protection and Civil Society in Europe, eds M. Feischmidt, L. Pries, and C. Cantat (Cham: Palgrave Macmillan), 291-313.

Garcés-Mascareñas, B., and Gebhardt, D. (2020). Barcelona: municipalist policy entrepreneurship in a centralist refugee reception system. Comparat. Migrat. Stud. 8:15. doi: 10.1186/s40878-020-0173-z

Garcés-Mascareñas, B., and Penninx, R. (eds.). (2020). "The concept of integration as an analytical tool and as a policy concept," in Integration Processes and Policies in Europe, Contexts, Levels and Actors (Cham: Springer), 23-122. doi: 10.1007/978-3-319-21674-4

Gerometta, J., Häussermann, H., and Longo, G (2005). Social innovation and civil society in urban governance: strategies for an inclusive city. Urban Stud. 42, 2007-2021. doi: 10.1080/00420980500279851

Kaldor, M. (2003). The idea of global civil society. Int. Affairs 79, 583-593. doi: 10.1111/1468-2346.00324

Krzyzanowski, M., Triandafyllidouh, A., Wodak, R. (2018). The mediatization and the politicization of the "Refugee Crisis" in Europe. J. Migrant Refugee Stud. 16, 1-14. doi: 10.1080/15562948.2017.1353189

Lahusen, C., and Grasso, T. M. (2018). Solidarity in Europe. Palgrave Macmillan.

Lönnaeus, O. (2015). Katrin Stjernfeldt Jammeh uppmanar Löfven: Gör upp snabbt! Sydsvenskan. Available online at: https://www.sydsvenskan.se/ 
2015-10-22/katrin-stjernfeldt-jammeh-uppmanar-lofven-gor-upp-snabbt (accessed May 26, 2020).

Lönnaeus, O. (2016). Gränsstopp i Sverige och Danmark. Sydsvenskan, 4 January. Available online at: https://www.sydsvenskan.se/2016-01-04/gransstopp-isverige-och-danmark-?redirected $=1$ (accessed on April 15, 2020).

Magnusson, E. (2015). Många vill hjälpa på Malmö Central. Sydsvenskan, 8 September. Available online at: https://www.sydsvenskan.se/2015-09-08/ manga-vill-hjalpa-pa-malmo-central (accessed on April 17, 2020).

Malmö Stad (2018). Malmö Stads kartläggning av hemlösheten år 2018. Malmö: Socialtjänsten.

Malmö Stad (2019). Program för att motverka hemlöshet. Malmö Stad: Fastighetsoch gatukontoret.

Malmö Stad Kommunfullmäktige (2018). Handlingsplan för bostadsförsörining 2018-2022. Malmö Stad.

Miciukiewicz, K., Moulaert, F., Novy, A., Musterd, S. and Hillier, J. (2012). Introduction: problematising urban social cohesion: a transdisciplinary endeavour. Urban Stud. 49, 1855-1872. doi: 10.1177/0042098012444877

Migrationsverket (2020a). Inkomna ansökningar om asyl, 2015. Available online at: https://www.migrationsverket.se/download/18.7c00d8e6143101d166d1aab/ 1485556214938/Inkomna\%20ans\%C3\%B6kningar\%20om\%20asyl\%202015 \%20-\%20Applications\%20for\%20asylum\%20received\%202015.pdf (accessed on April 14, 2020).

Migrationsverket (2020b). Olika Myndigheters Ansvar för Ensamkommande Barn Och Ungdomar. Available online at: https://www.migrationsverket.se/Andraaktorer/Kommuner/Om-ensamkommande-barn-och-ungdomar/Olikamyndigheters-ansvar.html (accessed on May 20, 2020).

Migrationsverket (2020c). Olika myndigheters ansvar för asylsökande. Available online at: https://www.migrationsverket.se/Andra-aktorer/Kommuner/Omasylsokande/Olika-myndigheters-ansvar.html (accessed on May 20, 2020).

Migrationsverket (2020d). Inkomna ansökningar om asyl, 2014. Available online at: https://www.migrationsverket.se/download/18.39a9cd9514a346077211b0a/ 1485556218186/Inkomna\%20ans\%C3\%B6kningar\%20om\%20asyl\%202014 \%20-\%20Applications\%20for\%20asylum\%20received\%202014.pdf (accessed on April 15, 2020).

Nord, K. (2019). Frivilligorganisationer larmar: Det behövs en större kraftsamling mot hemlösheten. Sydsvenskan. Available online at: https:// www.sydsvenskan.se/2019-03-12/frivilligorganisationer-larmar-det-behovsen-storre?redirected $=1$ (accessed February 25, 2020).

Nordström, I. (2015). Flyktingar sover I kyrkan. Aftonbladet. Available online at: https://www.aftonbladet.se/nyheter/a/ddrWaB/flyktingar-sover-ikyrkan (accessed on February 09, 2021).

Novy, A., Swiatek, D., and Moulaert, F. (2012). Social cohesion: a conceptual and political elucidation. Urban Stud. 49, 1873-1889. doi: $10.1177 \% 2 \mathrm{~F} 0042098012444878$

Oliver, C., Dekker, R., Geuijen, K., and Broadhead, J. (2020). Innovative strategies for the reception of asylum-seekers and refugees in European cities: multi-level governance, multi-sector urban networks and local engagement. Comparat. Migrat. Stud. 8:30. doi: 10.1186/s40878-020-00189-y

Patel, B. R., and Gleason, M. K. (2018). The association between social cohesion and community resilience in two urban slums of Port au Prince, Haiti. Int. J. Disaster Risk Reduct. 27, 161-167. doi: 10.1016/j.ijdrr.2017.10.003

Pedersen, H. (2015). Flyktingström gör att Malmö inför krisläge två. Sydsvenskan. Available online at: https://www.sydsvenskan.se/2015-1006/flyktingstrom-gor-att-malmo-infor-krislage-tva (accessed on April $16,2020)$.

Pries, L. (2019). "Introduction: civil society and volunteering in the so-called refugee crisis of 2015-Ambiguities and Structural Tensions," in Refugee Protection and Civil Society in Europe, eds M. Feischmidt, L. Pries, and C. Cantat (Cham: Palgrave Macmillan), 1-18.

Punch, K. (2005). Introduction to Social Research, Quantitative and Qualitative Approaches. 2nd edn. London: Sage Publications. p. 144.

Righard, E., and Öberg, K. (2020). Integration Governance in Sweden: Accommodation, Regeneration and Exclusion. GLIMER Report Series No. 3. Malmö: Malmö University. Available online at: http://www.glimer. eu/wp-content/uploads/2019/07/Sweden-Accommodation-1.pdf (accessed on February 24, 2020).

Rosén, H., and Olsson, H. (2017). Regeringen kritiseras för bristande styrning. Dagens Nyheter. Available online at: https://www.dn.se/arkiv/ nyheter/regeringen-kritiseras-for-bristande-styrning/ (accessed on March 25, 2020).

Rydhagen, M. (2015). Volontärer utbrända: "Svårt att gå hem.” Expressen. Available online at: https://www.expressen.se/kvallsposten/volontarerutbranda-svart-att-ga-hem/ (accessed on January 04, 2020).

Scholten, P., and Penninx, R. (2020). "The multilevel governance of migration and integration," in Integration Processes and Policies in Europe, Contexts, Levels and Actors, eds B. Garcés-Mascareñas, and R. Penninx (Cham: Springer), 23.

SFS 2016:38. (2016). Lag om mottagande av vissa nyanlända invandrare för bosättning. Stockholm: Arbetsmarknadsdepartementet. Available online at: https://www.riksdagen.se/sv/dokument-lagar/dokument/svenskforfattningssamling/lag-201638-om-mottagande-av-vissa-nyanlanda_sfs2016-38 (accessed on March 25, 2020).

SFS 2016:752. (2016). Lag om tillfälliga begränsningar av möjligheten att få uppehållstillstånd $i$ Sverige. Stockholm: Justitiedepartementet L7. Available online at: https://www.riksdagen.se/sv/dokument-lagar/dokument/svenskforfattningssamling/lag-2016752-om-tillfalliga-begransningar-av_sfs-2016752

Silberstein, M. (2015). 2015 - året då flyktingkrisen stod i centrum. SVT Nyheter. Available online at: https://www.svt.se/nyheter/inrikes/2015-aret-daflyktingkrisen-stod-i-centrum (accessed on May 27, 2020).

Stadsbyggnadskontoret (2019). Lägesrapport För Bostadsförsöjningen. Malmö: Malmö Stad.

Statens Offentliga Utredningar 2019;56 (2019). Idéburet offentligt partnerskap. Vägledning. Stödmaterial till betänkande av Utredningen om Idéburna aktörer i välfärden. Stockholm.

Stigendal, M. (2010). Cities and Social Cohesion: Popularizing the results of Social Polis. MAIPUS-Series, No. 6. Malmö University: Department of Urban Studies.

Törngren, S., Öberg, K., and Righard, E. (2018). "The role of civil society in the integration of newly arrived refugees in Sweden," in Newcomer Integration in Europe: Best Practices and Innovations since 2015, ed A. Lace (Brussels: FEPS, Foundation for European Progressive Studies).

Townshend, I., Awosoga, O., Kulig, J., and Fan, H. (2014). Social cohesion and resilience across communities that have experienced a disaster. Natural Hazards 76, 913-938. doi: 10.1007/s11069-014-1526-4

TT (2019). Flyktingkrisen som skakade Europa. Sydsvenskan, 8 October. Available online at: https://www.sydsvenskan.se/2019-10-08/flyktingkrisensom-skakade-europa (accessed on May 05, 2020).

UNHCR (2015). Refugees From Syria: Lebanon. United Nations. Available online at: https://data2.unhcr.org/en/documents/download/45764 (accessed on May 03, 2020).

United Nations (2015). Habitat III Issue Papers - Migration and Refugees in Urban Areas. New York, NY: United Nations.

United Nations (2020). Goal 11: Make Cities Inclusive, Safe, Resilient and Sustainable. Available online at: https://www.un.org/sustainabledevelopment/ cities/ (accessed on April 03, 2020).

Vandevoordt, R., and Verschraegen, G. (2019). "Subversive humanitarianism and its challenges: notes on the political ambiguities of civil refugee support," in Refugee Protection and Civil Society in Europe, eds M. Feischmidt, L. Pries, and C. Cantant (Cham: Palgrave Macmillan).

Witkowski, J., Pries, L., and Mratschkowski, A. (2019). "Networks of refugee and asylum related organizations in the mediterranean Area of the European Union," in Refugee Protection and Civil Society in Europe, eds M. Feischmidt, L. Pries, and C. Cantant (Cham: Palgrave Macmillan).

Zetter, R. (2007). More labels, fewer refugees: remaking the refugee label in an Era of Globalization. J. Refugee Stud. 20, 172-192. doi: 10.1093/jrs/fem011

Conflict of Interest: The authors declare that the research was conducted in the absence of any commercial or financial relationships that could be construed as a potential conflict of interest.

Copyright (C) 2021 Fry and Islar. This is an open-access article distributed under the terms of the Creative Commons Attribution License (CC BY). The use, distribution or reproduction in other forums is permitted, provided the original author(s) and the copyright owner(s) are credited and that the original publication in this journal is cited, in accordance with accepted academic practice. No use, distribution or reproduction is permitted which does not comply with these terms. 